Commission, it might have trained its sights on the whale, the most formidable of Earth's creatures, instead of the foundering industry. Salvos are still being fired for an industry bent on disrupting fatally one of the most extraordinary legacies of the natural environment of our small planet. Is it likely that the sea will be celebrated by future poets, as in the past, when empty of Right, Bowhead, Blue and Humpback Whales?

Yours faithfully,

One Nassau Hall,

Scott McVay

Princeton University,

Princeton, New Jersey.

\section{Another Doctors' Dilemma}

SrR,-I am really surprised at the editorial in your issue of May 3 (Nature, 222, 401; 1969) which reads like a sneer at the Minister for Education and Science for "his advocacy of the Bible".

Most people would agree, I suppose, that the books of the Bible are of unequal value educationally and that the science in them is primitive, though not more so, of course, than that in documents of similar date or antiquity. Quite apart, however, from any religious significance that the Bible may have for a number of your regular readers, it is certainly arguable that it is the finest, and cheapest, collection of literature to be published under one cover. Those who think that the educational value of its teaching, its philosophy, its poetry and its stories, both historical and mythical, is low, should really spend a little time occasionally reading it, without bias.

We do not, of course, live up to the best of its teaching. If we did, we would be better people and better scientists.

\section{Yours faithfully,}

Kathleen Lonsdale

125a Dorset Road,

Bexhill-on-Sea,

Sussex.

\section{Indian Science Policy}

SrR,-I was interested to read E. B. Worthington's comments (Nature, 222, 397; 1969) on the article by Ashok Parthasarathy, "Appearance and Reality in Indian Science Policy" (Nature, 221, 909; 1969). He is quite right in pointing to the question of priorities of science not considered carefully in Indian science policy.

I can only confirm that Indian science has, until recently, grown more under personal guidance and influence than anything else. In this respect, Bhaba was no exception. Unfortunately, even after independence, overall planning of science and technology has continued to be guided by the personality factors. As a result, there has been a complete lack of coordination in science planning in India so far. Proper and timely emphasis has not been directed to biology, agriculture and indigenous industries to meet India's immediate requirements in food, consumer goods and employment. This has been mentioned by the writer on more than one occasion well in advance. May I conclude by quoting from two of my previous publications: "Therefore, in solving the food crisis all our efforts should be concentrated on war against hunger. Scientific researches should be concentrated on the technology and economics of food to find ways and means of improving food situation through $(a)$ increased acres under food crops, $(b)$ increased yield per acre, (c) adoption of better and more efficient methods in agriculture, $(d)$ better storage system, $(e)$ more efficient distributing machinery, and $(f)$ production and use of synthetic and substitute food with special reference to different income and age groups." (Sunday Hindusthan Standard, Calcutta and New Delhi, November 1, 1959.)

"It is not the fusion of atoms but the fusion of science and economics which is needed in India today. More stress should be laid on the proper and economic use of science, because the grim picture of food and employment is a challenge to the scientists, economists, planners, administrators, industrialists and politicians of India today." (From "Science and Technology in relation to Planning in India", J. Sci. Club, XIV, 185, 1961; Calcutta.)

Yours faithfully,

33 Trevellance Way,

S. K. GUHA

Watford,

Herts WD2 6LY.

\section{University News}

Dr J. K. Sutherland, Imperial College, University of London, has been appointed to the new chair of organic chemistry at Heriot-Watt University.

Dr D. W. Straughan, University of Edinburgh, has been appointed to the Wellcome chair of pharmacology tenable at the School of Pharmacy, University of London.

Dr E. R. Trueman, University of Hull, has been appointed professor of zoology at the University of Manchester in succession to Professor A. J. Cain.

Dr R. Davis, University of Reading, has been appointed to the chair of psychology at the University of Newcastle upon Tyne.

\section{Appointments}

Professor G. E. Blackman, Professor M. McGregor Cooper, Dr F. Fraser Darling and Dr J. E. Smith have been appointed members of the Nature Conservancy. Professor J. A. Kitching has retired. Mr A. W. Barbour, Professor F. G. T. Holliday and Dr G. D. Waterston have joined the conservancy's Scottish committee from which Dr C. H. Gimingham and Professor T. Neville George have retired. Professor A. D. Bradshaw, Professor J. H. Burnett, Mr G. D. Holmes, Dr J. Phillipson and Professor D. H. Valentine have joined the conservancy's scientific policy committee. They succeed Dr F. Fraser Darling, Professor T. Neville George, Professor C. Kidson, Professor J. N. Black and Professor V. C. Wynne-Edwards, who have retired. Dr David E. Coombe, Dr J. W. G. Lund and Mr J. Workman have joined the conservancy's committee for England. They succeed Mr T. Beresford, Professor P. J. Newbold and Professor J. A. Steers. Dr J. M. Edington, Dr W. S. Lacey and Professor H. Morris-Jones have joined the conservancy's committee for Wales on the retirement of Dr D. L. Carey Evans and Professor J. L. Harper.

\section{Announcements}

Mr D. H. Sadler, superintendent of HM Nautical Almanac Office, Royal Greenwich Observatory, has been awarded the medal of the Association for the International Development of the Nice Observatory, in recognition of his contribution to the development of astronomy and astrophysics and of the part which he plays in the establishment of international cooperation in this science.

Dr R. Kuntzman, Wellcome Research Laboratories, Tuckahoe, New York, has been awarded the John Jacob Abel Award presented by the American Society of Pharmacology and Experimental Therapeutics, in recognition of his work on drug interactions. 


\section{International Meetings}

June 4, Optimum in Optics, London (R. H. Sharpe, Daniel J. Edelman Ltd, 43 Albemarle Street, London W1E 7JZ).

September 16-17, Emulsion Polymers, Manchester (Registrar, University of Manchester Institute of Science and Technology, Sackville Street, Manchester M60 IQD, UK).

September 17-19, Blood and Tissue Antigens, Michigan (Dr D. Aminoff, Simpson Memorial Institute, University of Michigan, Ann Arbor, Michigan 48104, USA).

September 22, Chemical Society Protein Group, Liverpool (Secretary, The Chemical Society, Burlington House, London WIV OBN).

September 25-27, Variability in the North Atlantic, Dublin (Hans Tambs-Lyche, Secretary General, International Council for the Exploration of the Sea, Charlottenlund Slot, Charlottenlund, Denmark).

September 26-27, Histochemistry and Cytochemistry, Bucharest (Dr Ionel Caloenescu, Secretary General, Union of Medical Science Societies of the Socialist Republic of Rumania, 8 Rue Progresul, Bucharest, Rumania).

September 26-27, International League against Epilepsy, New York (Professor H. Gastaut, 87 Boulevard Perier, Marseilles 8, France).

October 6-10, Ultrasound in Medicine, Winnipeg ( $\mathrm{Dr}$ R. E. Brown, American Institute of Ultrasound in Medicine, Department of Continuing Medical Education, 15 Medical College Building, Bannatyne and Emily Streets, Winnipeg 3, Manitoba, Canada).

October 7-10, Information Processing in Measurement Systems, Pezinok, Czechoslovakia (IMEKO Secretariat, Budapest 5, POB 457, Hungary).

October 13-15, Industrial Reciprocating and Rotary Compressors-Design and Operational Problems, London ( $\mathrm{Mr}$ Wall, Groups Department, Institution of Mechanical Engineers, 1 Birdcage Walk, London SW1).

October 16, High Speed Freight Wagons, London (Mr Davies, Groups Department, Institution of Mechanical Engineers, 1 Birdcage Walk, London SW1).

October 20-22, Electrical Insulation and Dielectric Phenomena, Pennsylvania (Colonel R. A. Cliffe, Staff Executive, Conference on Electrical Insulation and Dielectric Phenomena, National Academy of Sciences, 210 Constitution Avenue, NW, Washington DC 20418, USA).

\section{Sabbatical Itinerants}

In the hope of providing some practical assistance in the good cause of mobility between laboratories, Nature advertises the needs for housing of families about to take up periods of sabbatical leave. To begin with, no charge will be made for advertisements like this. It is hoped that a period of experiment will show what form these advertisements could most usefully take and whether they are effective.

Vacant: Furnished house, $2-3$ bedrooms, in Batter sea Park district of London for one year from September 1, 1969. Good access to central London. Please contact: Dr J. Craske, Virus Reference Laboratory, Central Public Health Laboratory, Colindale Avenue, London NW9. Telephone 01-205 7041, Ext. 27.

Wanted: Furnished house, 4 or 5 bedrooms, London area, for 12 months from mid-August, for Stanford (California) professor and family. Please phone Mrs D. C. Ritson, 01-794 4815, between 10.30 and 11 a.m.

\section{BRITISH DIARY}

\author{
Monday, June 2
}

UNIVERSITY OF LONDON (at the Wright-Fleming Institute, St Mary's Hospital Medical School, Norfolk Place, London, W2), at 5 p.m.- - Professor D. A. Price Evans "Genetic Aspects of Drug Therapy" (last of a series of four Almroth Wright Lectures).

Tuesday, June 3-Wednesday, June 4

Institure of RURal Life at HoMe and Overseas (at the Ministry O Overseas Development, Eland House, Stag Place, London, SW1), at 10.30 a.m. daily-Conference on "Man's Changing Environment".

Tuesday, June 3-Thursday, June 5

INSTITUTION OF ELECTRICAL ENGINEERS (in association with the Institution of Electronic and Radio Engineers, the Institute of Physies and the Physica (1)

Wednesday, June 4

UnIVersity of LoNdon (at the Royal Postgraduate Medical School, Du Cane Road, London, W12), at 11 a.m.-Dr M. Machover: "Selected Topics in Recursion Theory".

UnIVERsity of London (at the Chelsea College of Science and Technology, Manresa Road, London, SW3), at 2.45 p.m.-Professor Arthur Fine: "Philosophical Problems of Quantum Physics".

Thursday, June 5

ROYAL SOCIETY (at 6 Carlton House Terrace, London, SW1), at 10 a.m.Discussion Meeting on "Duality-Reggeons and Resonances in Elementary Perkins, FRS, and Professor C. F. Powell, FRS.

ROYAL COLLEGE OF SURGRONS OF ENGLAND (at Lincoln's Inn Fields, London, WC2), at 5 p.m.--Professor Sir Ashley Miles, FRCP, FRS: "The Plasma Kinin System: Fact and Fancy" (Fifth Michael Cross Memorial Lecture).

Friday, June 6

UnIversity OF London (at the Royal Postgraduate School, Du Cane Road, London, W12), at 11 a.m.--Professor C. V. Harrison: "Inflammatory Diseases of Arteries".

Saturday, June 7

BRITISH INSTITUTE OF RADIOLOGY (joint meeting with the North of Fngland Branch, at'the University of Sheffield), at 9.45 a.m.-Symposium on "Renal Tumours"; meeting on Radiodiagnosis and Radiotherapy.

Monday, June 9-Friday, June 20

IMPERIAL COLLEGE OF SCIENCE AND TRCHNOLOGY, APPLIED OPTICS SECTION (at Prince Consort Road, London, SW7)-Summer School on "Applied Optics".

\section{REPORTS and other PUBLICATIONS}

(not included in the monthly Books Supplement)

Great Britain and Ireland

Royal Irish Academy. Register of Scientific Research Personnel, January 1968. Pp ix + 102. (Dublin: Royal Irish Academy, 1968.) 20s. [214 Ministry of Transport: Road Research Laboratory. RRL Report LR 226: The Effect of Road and Traffic Conditions on Fuel Consumption Everall. Pp. ii $+27+8$ plates. (Crowthorne: Road Research Laboratory

Department of Employment and Productivity. A National Minimum Wage: Report of an Inter-Departmental Working Party. Pp. vii +89 . (Wage: Report of an Inter-Departmental Working Party. Pp. vil +
[214 University of Oxford. Lord Nuffield's Benefaction for the Advancement of Medicine-Report for 1966-67. Pp. 20. (Supplement No 2 to the University Gazette, Vol. 99, A pril 1969.) 5s. Annual Reports 1967-1968. Pp. 36. (Supplement No. 5 to the University Gazette, Vol. 99, April 1969.) $5 s$.
[214 Il Muro di Adriano. (Breve guida compilata del Ministero delle Construzioni e dei Lavori Pubblici.) Pp. 12. (London: HM Stationery Office, 1969.) 1s. $6 d$. net. Bujlding Research Station Digest, No. 104: Floor Screeds. Pp. 8. (London: HM Stationery Office, 1969.) $6 \dot{d}$. Geomagnetic Bulletins of the Institute of Geological Sciences. No. 1: Hartland Observatory-Magnetic Results, 1965, 1966, 1967. Pp. 159. Unives of University of Oxford. Schedules of Lectures authorized by Boards of Faculties, Trinity Term 1969. (Supplement (2) to Oxford 0 . $2 s$.
[23 Ministry of Transport: Road Research Laboratory. RRL Report LR 234: The Thermal Behaviour of the Beachley Viaduct/Wye Bridge. By M. W. R. Capps. Pp. iii $+25+5$ plates. (Crowthorne, Berkshire: Road Research Laboratory, 1968.) Gratis. 